\title{
Baut Syefixe
}

bon ben

\section{Redten des Zfandyläubigers \\ an ben}

\section{frücften der verpfändeten Saçje.}

Gine Studie ang Der praxis.

Bon

Reingolo Jojow,

Dber-Rzigunals-Phatb.

(Separat-robbrud aus ber Beitjurift für Bejesgebung uno Oredrspflege.)

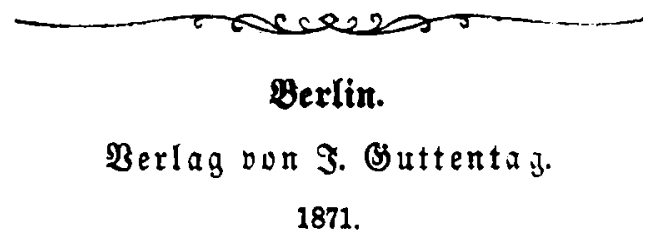


